\title{
Future Directions for Immunotherapy in Ovarian Cancer
}

\author{
Luisa Manning ${ }^{1}$ and John Nemunaitis ${ }^{1,2 *}$ \\ ${ }^{1}$ Gradalis, USA \\ ${ }^{2}$ Mary Crowley Cancer Research Center, USA
}

Submission: February 01, 2017; Published: February 08, 2017

*Corresponding author: John Nemunaitis, Mary Crowley Cancer Research Center, 12222 Merit Drive Suite1500, Dallas, Texas, USA, 75251,

Tel: 214-658-1964; Fax: 214-658-1992; Email: jnemunaitis@marycrowley.org

\begin{abstract}
Immunotherapies involving cellular and checkpoint inhibitor approaches are under investigation in ovarian cancer and preliminary results suggest evidence of clinical benefit. Assumptions in the past of low immunogenicity of ovarian cancer appear to be changing as our new awareness of immune function activity with ovarian cancer, tumor microenvironment and molecular signaling is becoming evident. Anticancer response, survival advantage, and developing program progression have been observed in immunotherapy approaches involving ovarian cancer patients. Herein, we review current progress of cellular immunotherapy and checkpoint inhibitor approaches in ovarian cancer.
\end{abstract}

Keywords: Immunotherapy; Molecular signaling; Checkpoint inhibitor

\section{Introduction}

A recent open-label Phase IIa study of Vigil immunotherapy $(n=31)$ vs SOC observation $(n=11)$ involving high risk stage IIIc/IV ovarian cancer patients in clinical complete remission following surgical debulking and frontline chemotherapy has shown a decrease in tumor recurrence (61\% vs $82 \%$ ) and increase in median progression free survival 604 vs 377 days ( $p=0.033$, HR $0.43,95 \%$ CI $(0.19,0.96)$ [1] to Vigil immunotherapy. Clinical immune response to Vigil was measured by tracking circulating immune effector cells against autologous tumor before and sequentially after Vigil via $\gamma$ IFN-ELISPOT assay. All 31 Vigil treated patients and 10/10 control patients (1 unevaluable) were baseline negative. After Vigil administration, all patients showed $\gamma$ IFN-ELISPOT conversion to positive with induction of tumor-antigen specific $\mathrm{T}$ effector cells. Interestingly 7/8 control patients, of which all were negative at time of relapse, converted to $\gamma$ IFN-ELISPOT positive after cross-over to Vigil therapy (as per trial design) after relapse. A currently ongoing double blind randomized study in the same patient population is investigating further clinical benefit and immune analysis of Vigil (NCT02346747).

Multiple check point inhibitors are also currently in development in the maintenance setting or in recurrent, platinum-resistant or refractory ovarian cancer. Response rates in ovarian cancer to anti-CTLA-4 therapy have been observed [2] but at slightly lower frequency than PD-1/PD-L1 inhibitors [3]. Given this and a higher perceived toxic response to anti-CTLA-4 inhibitors over PD-1/PD-L1 inhibitors most clinical explanation in ovarian and other women's cancers is involving PD-1/PDL1 inhibitors. Results of an initial clinical trial of an anti-PD-1 antibody, nivolumab, published by Hamanishi et al. [3] reported on response rate of $15 \%$ in 20 advanced ovarian cancer patients and a median PFS of 3.5 months across 2 cohorts $(1$ or $3 \mathrm{mg} /$ $\mathrm{kg}$ nivolumab dose) [3]. Other studies involving pembrolizumab (ORR 11.5\%, 3/26) [4] and avelumab (ORR 11\%, 8/75) [5] have shown similar response activity. Hamanishi et al also reported that high PD-L1 expression in ovarian cancer cells is associated with a poor prognosis [6]. Another hypothesis supported by preclinical and clinical data is that effective anticancer response following anti-PD-1/PD-L1 therapy requires the intratumoral presence of pre-existing tumor-specific CTLs that are held in check by the PD-1/PD-L1 pathway. Conversely, in the absence of infiltrating activated $\mathrm{T}$ cells, there is only limited rationale for checkpoint inhibitor therapy targeting PD-1/PD-L1.

Tumeh et al. [7] reported on 46 patients with advanced melanoma who were treated with single agent PD-1 inhibitor pembrolizumab demonstrating higher levels pre-existing CD8 
positive, PD-1 positive and PD-L1 positive cells at the invasive tumor margin and in the tumor in the responding patient's on-study tumor biopsies vs non-responders [7]. Herbst et al. [8] reported on 277 patients treated with the PD-L1 inhibitor MPDL3280A and noted that across tumor types, high PD-L1 ligand expression on tumor cells, and particularly on tumor infiltrating immune cells (TILs), was predictive of objective response by RECIST 1.1 criteria to PD-L1 inhibitor treatment [8]. This evidence suggestsPD-L1/PD-1 inhibitor activity being significantly correlated with high activated T cell involvement/ migration into the autologous tumor bed.

In addition, PD-1 expression can be adaptively upregulated following T-cell activation, suggesting that PD-L1 expression, a mechanism of resistance to immune mediated tumor killing, is also predictive of response to PD-1/-L1 inhibitors and other immunotherapies [8].

\section{Conclusion}

Vigil upregulation of circulating $\mathrm{T}$ effector cell activity against autologous tumor cells is induced by a novel mechanism involving three pathways: 1) blockade of tumor-induced immune escape by bi-shRNAfurin knockdown resulting in marked local tumor reduction in TGF $\beta 1$ and 2, 2) GMCSF-induced antigen presentation and dendritic cell activation, 3) evidence of TCR induction to relevant tumor neoantigens by utilizing patient's autologous tumor cells. As such, it appears rational to explore the effect of Vigil in combination with PD-1/PD-L1 inhibitor therapy in advanced ovarian cancer patients. Other preclinical studies in Panc02 xenograft mouse models support the rationale of combining all three components of anticancer immune response: a) GMCSF increase, b) TGF $\beta$ knockdown, and c) PD1/-L1 blockade [9].

Tumor burden was significantly reduced and overall survival prolonged in Panc02 or KPC xenograft mice treated with the combination of GVAX, a systemic TGF $\beta$ a and PD- 1 antibody compared to monotherapy of each, or the combination of GVAX and TGFßa only. Further, the combination of cyclophosphamide/ GVAX + monoclonal antibody targeting PD-1 significantly increased the percentage of IFN $\gamma$-producing T cells within TILs as well as greater CD8+ T cell IFN $\gamma$ secretion compared to either cyclophosphamide/GVAX or anti-PD-1 alone [10]. A similar murine study has been initiated in CT26 xenograft mice treated with GVAX +/- TGFßa and murine Vigil-CT26 +/- systemic TGF $\beta$ a to explore and compare the tumor response, survival, and immune functions following either immunotherapy regimen vs. no treatment.

With the rationale of previously published preclinical results [9] and this ongoing experiment, supporting a combination studies of an anti-PD-L1 antibody, Atezolizumab with Vigil a study in platinum-refractory or resistant, recurrent ovarian cancer is currently in future development. Endpoints are the evaluation of safety and anti-tumor activity of the combination in women with advanced ovarian or gynecological cancers, (ie. primary uterine, endometrial), biomarker characterization for the anti-tumor systemic immune response generated by Vigil alone, atezolizumab alone or the combination of the two agents, tumor response and survival.

\section{Acknowledgements}

The authors would like to acknowledge Brenda Marr and Michelle Richey for their competent and knowledgeable assistance in the preparation of the manuscript.

\section{Disclosure/Conflict of Interest}

The following authors are shareholders in Gradalis, Inc.: John Nemunaitis. The authors have no other relevant affiliations or financial involvement with any organization or entity with a financial interest in or financial conflict with the subject matter or materials discussed in the manuscript.

\section{References}

1. Oh J, Barve M, Matthews CM, Koon EC, Heffernan TP, et al. (2016) Phase II study of Vigil (R) DNA engineered immunotherapy as maintenance in advanced stage ovarian cancer. Gynecol Oncol 143 (3): 504-510.

2. Hodi FS, Butler M, Oble DA, Seiden MV, Haluska FG, et al. (2008) Immunologic and clinical effects of antibody blockade of cytotoxic $\mathrm{T}$ lymphocyte-associated antigen 4 in previously vaccinated cancer patients. Proc Natl Acad Sci USA 105(8): 3005-3010.

3. Hamanishi J, Mandai M, Matsumura N, Abiko K, Baba T, et al. (2016) PD-1/PD-L1 blockade in cancer treatment: perspectives and issues. Int J Clin Oncol 21(3): 462-473.

4. Varga A, Piha-Paul S, Ott PA, Mehnert JM, Berton-Rigaud D, et al. ( 2015) Antitumor activity and safety of pembrolizumab in patients (pts) with PD-L1 positive advanced ovarian cancer: Interim results from a phase Ib study. In: American Society of Clinical Oncology Chicago, J Clin Oncol 33(suppl).

5. Disis ML, Patel MR, Pant S, Infante JR, Lockhart C, et al. (2015) Avelumab (MSB0010718C), an anti-PD-L1 antibody, in patients with previously treated, recurrent or refractory ovarian cancer: A phase Ib, open-label expansion trial. In: American Society of Clinical Oncology Chicago, IL: J Clin Oncol 33(suppl).

6. Hamanishi J, Mandai M, Abiko K, Matsumura N, Baba T, et al. (2011) The comprehensive assessment of local immune status of ovarian cancer by the clustering of multiple immune factors. Clin Immunol 141(3): 338-347.

7. Tumeh PC, Harview CL, Yearley JH, Shintaku IP, Taylor EJ, et al. (2014) PD-1 blockade induces responses by inhibiting adaptive immune resistance. Nature 515(7528): 568-571.

8. Herbst RS, Soria JC, Kowanetz M, Fine GD, Hamid O, et al. (2014) Predictive correlates of response to the anti-PD-L1 antibody MPDL3280A in cancer patients. Nature 515(7528): 563-567.

9. Soares KC, Rucki AA, Kim V, Foley K, Solt S, et al. (2015) TGF-beta blockade depletes $\mathrm{T}$ regulatory cells from metastatic pancreatic tumors in a vaccine dependent manner. Oncotarget 6(40): 43005- 43015.

10. Soares KC, Rucki AA, Wu AA, Olino K, Xiao Q, et al.( 2015) PD-1/PDL1 blockade together with vaccine therapy facilitates effector T-cell infiltration into pancreatic tumors. J Immunother 38(1): 1-11. 
This work is licensed under Creative Commons Attribution 4.0 License

DOI: 10.19080/JGWH.2017.02.555587

\section{Your next submission with Juniper Publishers} will reach you the below assets

- Quality Editorial service

- Swift Peer Review

- Reprints availability

- E-prints Service

- Manuscript Podcast for convenient understanding

- Global attainment for your research

- Manuscript accessibility in different formats ( Pdf, E-pub, Full Text, Audio)

- Unceasing customer service

Track the below URL for one-step submission https://juniperpublishers.com/online-submission.php 